\title{
INTRAEPITHELIAL LYMPHOCYTES IN THE DUODENAL MUCOSA OF MEAT QUAILS RECEIVING DIETS CONTAINING OR NOT CONTAINING PROBIOTIC AND DIFFERENT LEVELS OF CRUDE PROTEIN
}

\author{
Andressa Zardo \\ Luciana Kazue Otutumi ${ }^{2}$ \\ Taniara Suelen Mezalira ${ }^{3}$ \\ Fabiane Antiquera Ferreira ${ }^{14}$ \\ Igor Eduardo Dias Cestari ${ }^{5}$ \\ Patrícia Franco Gonçalves Previato do Amaral ${ }^{6}$ \\ Alysson Polzonoff Silveira
}

ZARDO, A.; OTUTUMI, L. K.; MEZALIRA, T. S.; FERREIRA, F. A.; CESTARI, I. E. D.; PREVIATO DO AMARAL, P. F, G.; SILVEIRA, A. P. Intraepithelial lymphocytes in the duodenal mucosa of meat quails receiving diets containing or not probiotic and different levels of crude protein. Arq. Ciênc. Vet. Zool. UNIPAR, Umuarama, v.18, n.2, p. 83-86, abr./jun. 2015.

\begin{abstract}
The aim of this study is to evaluate the effect of probiotic supplementation associated to different levels of crude protein (CP) on the count of intraepithelial lymphocytes (IELs) in the duodenum of meat quails. A total of 2304 quails were distributed in a completely randomized design in a $2 \mathrm{x} 4$ factorial scheme (with and without probiotic and four levels of CP - 15, 20, 25 and 30\%), with two replicates per treatment in two experimental periods, in a total of 32 experimental units. At seven days old, two quails from each experimental unit were euthanized to harvest the duodenum segment. Semi-serial 7- $\mu \mathrm{m}$ histological sections were obtained, which were subsequently stained with hematoxylin-eosin to perform the IEL count. For the calculation, first 2500 epithelial cells were counted from the mucosa of each animal, and then the IELs present between these cells were counted, with the results expressed in amounts of IELs/100 epithelial cells. No differences were found in the IEL count among the treatments. Under the experimental conditions, it can be concluded that the use of probiotic associated to different levels of CP supplementation does not alter the IEL count in the duodenum of meat quails.
\end{abstract}

KEYWORDS: Poultry. Enterocytes. Lymphocytes. Intestinal mucosa. Intestinal microbiota.

\section{LINFÓCITOS INTRAEPITELIAIS NA MUCOSA DO DUODENO DE CODORNAS DE CORTE RECEBENDO DIETAS CONTENDO OU NÃO PROBIÓTICO E DIFERENTES NÍVEIS DE PROTEÍNA BRUTA}

RESUMO: O objetivo deste trabalho foi avaliar o efeito da suplementação de probiótico associado com diferentes níveis de proteína bruta (PB) sobre a contagem de linfócitos intraepiteliais (LIEs) no duodeno de codornas de corte. Um total de 2304 codornas foram distribuídas em um delineamento inteiramente casualizado em esquema fatorial 2 x 4 (com e sem probiótico e quatro níveis de $\mathrm{PB}-15,20,25$ e $30 \%$ ), com duas repetições por tratamento em dois períodos experimentais, totalizando 32 unidades experimentais. Aos sete dias de idade, duas codornas de cada unidade experimental foi eutanasiada para colheita do segmento do duodeno. Cortes histológicos semi-seriados de sete $\mu \mathrm{m}$ foram obtidos, os quais foram posteriormente corados com hematoxilina-eosina para realização da contagem de LIEs. Para o cálculo, primeiro foram contados 2500 células epiteliais da mucosa de cada animal, e então os LIEs presentes entre essas células foram contados e os resultados expressos como quantidade de LIEs / 100 células epiteliais. Não foram encontradas diferenças entre os tratamentos na contagem de LIEs. Nas condições em que o experimento foi desenvolvido, conclui-se que o uso de probiótico associado a diferentes níveis de PB não altera a contagem de LIEs do duodeno de codornas de corte.

PALAVRAS-CHAVE: Aves. Enterócitos. Linfócitos. Mucosa intestinal. Microbiota intestinal.

\section{LINFOCITOS INTRAEPITELIALES EN LA MUCOSA DUODENAL DE CODORNICES DE ABATE RECIBIENDO DIETAS CON O SIN PROBIÓTICO Y DIFERENTES NIVELES DE PROTEÍNA BRUTA}

RESUMEN: Esta investigación buscó evaluar el efecto de suplementos probióticos asociados a diferentes niveles de proteína bruta (PB) sobre el contaje de linfocitos intraepiteliales (LIEs) del duodeno de codornices de abate. Un total de 2304 codornices fueron distribuidas en un delineamiento enteramente casualizado en esquema factorial 2x4 (con y sin probiótico y cuatro niveles de PB $-15,20,25$ y $30 \%$ ), con dos repeticiones por tratamiento, en dos períodos experimentales, totalizando 32 unidades experimentales. A los siete días de edad, dos codornices de cada unidad experimental sufrieron eutanasia, para

DOI: https://doi.org/10.25110/arqvet.v18i2.2015.5377

${ }^{1}$ Acadêmica do curso de Farmácia da Universidade Paranaense, Unipar, bolsista de fixação de recursos humanos do CNPq nível 1, Praça Mascarenhas de Moraes, 4282, Centro, 87502-210. andressa zardo@hotmail.com

${ }^{2}$ Professora do curso de Medicina Veterinária e do Mestrado em Ciência Animal da Unipar, Praça Mascarenhas de Moraes, 4282, Centro, Umuarama - Pr, 87502-210, otutumi@unipar.br;

${ }^{3}$ Acadêmica do curso de Medicina Veterinária da Unipar, bolsista PEBIC/CNPq

${ }^{4}$ Acadêmica do curso de Farmácia da Unipar, bolsista PEBIC/CNPq.

${ }^{5}$ Médico Veterinário formado pela Universidade Paranaense, Unipar, campus de Umuarama.

${ }^{6}$ Mestre em Ciência Animal pelo Programa de Pós Graduação em Ciência Animal da Unipar. 
colecta de segmento del duodeno. Se obtuvo cortes histológicos semi seriados con sete $\mu \mathrm{m}$, que fueron posteriormente colorados con hematoxilina-eosina para realización de contaje de LIEs. Para el cálculo, primeramente se contó 2500 células del epitelio de la túnica mucosa de cada animal, y en seguida los LIEs presentes entre esas células, siendo los resultados expresos en cantidad de LIEs/100 células epiteliales. No hubo diferencias en el contaje de LIEs en función de los tratamientos. En las condiciones en que el experimento se realizó, se puede concluir que el uso de probiótico asociado a diferentes niveles de suplementos de PB no altera el contaje de LIEs en el duodeno de codornices de abate.

PALABRAS CLAVE: Aves. Enterocitos. Linfocitos. Mucosa intestinal. Microbiota intestinal.

\section{Introduction}

Intestinal mucosal surfaces play a key role in the exclusion and elimination of potentially harmful dietary antigens and enteric micro-organisms and, with the intestinal microflora, they are essential to maintaining healthy flocks and minimizing losses associated to various diseases and stressors (DALLOUL et al., 2003). Thus, the use of additives such as probiotics might benefit the animals, since, according to Fuller (1989), these are food additives constituted of live microorganisms capable of bringing benefits to the host by means of an equilibrium of the intestinal microbiota, admittedly presenting immune-modulating effect (ERICKSON; HUBBARD; 2000; EDENS, 2003; LODDI, 2003; NG et al., 2009).

The bacterium genera present in probiotics directly related to the increase in immunity of poultry are Lactobacillus and Bifidobacterium, mainly when related to diseases affecting the gastrointestinal tract (ERICKSON; HUBBARD, 2000; MENTEN, 2002).

Several studies suggest that the immune-modulatory effect of probiotics takes place by means of interaction with dendritic cells, activation of macrophages, stimulation of $\mathrm{T}$ cells, increase in the production of immunoglobulins, antibodies and cytokines (OLIVEIRA et al., 2002; PANCHENIAK, 2005). Particularly, bacterial colonization of the intestine and infection by enteropathogens have an impact on the number of intraepithelial lymphocytes (IELs) associated with the intestinal tract (SCHAREK et al., 2007). Intraepithelial lymphocytes (IELs) are lymphocyte aggregates scattered along the gastrointestinal tract intraepithelium together with lamina propria lymphocytes (LPL), forming the gut-associated lymphoid tissue (GALT) in chicken (SHARMA, 1998), which play an important role in protecting against mucosal infections.

Thus, the objective of this study is to evaluate if probiotic supplementation to the diet of meat quails associated to different levels of crude protein alter the count of intraepithelial lymphocytes in the duodenum mucosa.

\section{Material and Method}

In this experiment, a total of 2304 meat quails distributed in a completely randomized experimental design in a 2 x 4 factorial scheme (with and without probiotic; four levels of crude protein - 15, 20, 25 and 30\%) with two replications per treatment, in two experimental periods were used.

The probiotic was provided, via feed, during seven days, containing an average of $1.6 \times 10^{9}$ Colony Forming Units (CFU) per gram from a pool of Lactobacillus sp, given in the dosage of $200 \mathrm{~g}^{\text {ton }}{ }^{-1}$ feed.

Feeds were formulated according to the demands proposed by Barral (1994), and the composition of food, ac- cording to Rostagno et al. (2005), in order to be isocaloric, with a varied level of crude protein.

At seven days of age, two birds from each repetition (eight birds per treatment) were euthanized for the removal of the duodenal segment for the counting of intraepithelial lymphocytes (IELs) in the mucosa. After collection, the samples were rinsed in saline solution, fixed in bouin solution and later, dehydrated in series in an ascending concentration of alcohol, diaphanized in xylene and included in paraffin, according to the methodology described by Beçak and Paulete (1976).

Longitudinal and semi-serial histological cuts with 7- $\mu \mathrm{m}$ thickness were obtained, which were later dyed by the hematoxylin-eosin method. For counting, images were captured using a digital camera (Moticam 2000, 2.0 megapixels $\left.^{\circledR}\right)$ attached to a trinocular light microscope equipped with an image-analyzing system (Motic Image Pro-Plus, v. $\left.2.0^{\circledR}\right)$. After capturing the images $(40 \mathrm{x}$ lens), the IEL count was performed using an image analyzing system. First, 2500 cells were counted from the mucous duodenum in each animal. Then, the IELs present within these cells were counted, and the results were expressed in the IELs/100 epithelial cells ratio.

The statistical analysis was performed by means of Analysis of Variance for experiments in factorial schemes, using the statistics program SPSS v. 20.0.

\section{Results and Discussion}

There were no differences in the lymphocytes/epithelial cells ratio from the duodenum of meat quails at seven days of age, receiving or not receiving probiotics associated to different levels of crude protein in feed (Table 1).

Table 1: Mean \pm std. error for lymphocytes/enterocytes ratio in the duodenal mucosa of quails at seven days of age regarding the protein level and probiotic supplementation.

\begin{tabular}{cc}
\hline Crude protein level & $\begin{array}{c}\text { lymphocytes/enterocytes } \\
\text { ratio }\end{array}$ \\
\hline 15 & $5.17 \pm 0.49$ \\
20 & $5.47 \pm 0.60$ \\
25 & $5.39 \pm 0.42$ \\
30 & $5.54 \pm 0.60$ \\
Probiotic & \\
Without & $5.54 \pm 0.33$ \\
With & $5.24 \pm 0.39$ \\
Probability & \\
Protein Level & 0,933 \\
Probiotic & 0,629 \\
Protein Level x Probiotic & 0,054 \\
\hline
\end{tabular}


In mice, Roselli et al. (2009) found that the use of probiotics prevented colitis experimentally induced by intra-rectal administration of trinitrobenzene sulfonic acid (TNBS). The Mix1 (Lactobacillus acidophilus and Bifidobacterium longum) protection was associated to a reduction in CD4(+) cells of IELs and LPLs (lamina propria lymphocytes), an increase in gamma delta T cells of IELs, and a decrease in gamma delta T cells of LPLs. Similarly, Scharek et al. have found that the population of intraepithelial CD8+ T cells was significantly enhanced in the probiotic group of piglets receiving Bacillus cereus var. toyoi. Likewise, Dalloul et al. (2003) have stated that birds on a probiotic diet had more IEL expressing the surface markers CD3, CD4, $\mathrm{CD} 8$, and $\alpha \beta$ TCR than those in the control diet.

One of the justifications for the absence of significant results in relation to the IEL number in the present study might be the fact that the animals had been raised in optimum sanitary conditions, justified by the low mortality $(1-2 \%)$, so that there were no stimuli for a greater proliferation of defense cells, such as IELs.

According to Havenaar and Spanhaak (1994), the immune-modulating effect of probiotics in poultry happens in two ways: (a) from the microbiota, in which the probiotic migrates along the intestine wall and is multiplied to a limited extension, or (b) the antigen released by the dead micro-organisms is absorbed and thus stimulates the immune system.

Chai and Lillehoj (1988) and Lillehoj (1989) found that IEL could participate in modulating intestinal immunity by both non-special immune mechanisms and special immune mechanisms, and the number of IEL might be associated with the immune-activating status.

Furthermore, Fuller (1986) emphasizes that the specificity of adhesion of lactobacilli (one of the most used probiotic genre in poultry) to epithelial cells is specific host and if the colonization is reached, it is essential to administer bacteria that have been originated form the host species for which they are being given. In this paper, the probiotic used was produced from the isolation of Lactobacillus spp. originated from the microbiota of meat chicken. On the other hand, Schneity and Nutio (1992) shows that the natural microbiota of chicken and turkey provide reciprocal protection for chicks and poults.

Currently, manipulating the diet to provide an improvement in the immune system of meat poultry is seen as an alternative for many producers, since the lack of nutrients might decrease the immunological function of the bird, and, as a consequence, harm the performance and bring losses to the producer. Particularly regarding protein and amino acids, studies have shown the effects of dietary protein (JAHANIAN, 2009), especially lysine (COSTA et al., 2001) methionine (ZHANG; GUO, 2008) and arginine (KIDD et al., 2001). However, in the present study, the effect of the protein on the count of IELs from the duodenum of meat quails was not found (Table 1).

On the other hand, in piglets, Gu and Li (2004) verified that dietary crude protein had a significant effect on the IELs of duodenum $(p=0.053)$, proximal jejunum $(p<0.05)$, distal jejunum $(p=0.055)$ and ileum $(p<0.05)$, which showed quadratic decrease as the dietary $\mathrm{CP}$ increased from 63 to 208 $\mathrm{g} \mathrm{kg}-1$ diet. According to the authors, this may imply that
CP208 treatment was suitable for the pig and that there was no need of surplus protein to activate the immune system of the intestine and lead to an increase in IELs.

\section{Conclusions}

Under the conditions in which the study was performed, the use of probiotics associated to different levels of crude protein did not change the count of intraepithelial lymphocytes from the duodenum mucosa in meat quails.

\section{Referênces}

BARRAL, A. D. Manual de la codorniz: cria industrial y para la caza. Lleida: Dilagro, 1994. p. 268.

BEÇAK, W.; PAULETE, J. Técnicas de citologia e histologia. Rio de Janeiro: Livros Técnicos e Científicos, 1976.

CHAI, I. Y.; LILLEHOJ, H. Isolation and functional characterization of chicken intestinal intraepithelial lymphocytes natural killer cell activity against tumor target cells. Immunology, v. 63 p. 111-117, 1988.

COSTA, F. G. P. et al. Níveis dietéticos de lisina para frangos de corte de 1 a 21 e 22 a 40 dias de idade. Revista Brasileira de Zootecnia, v. 30 n. 5, p. 1490-1497, 2001.

DALLOUL, R. A. et al. Enhanced mucosal immunity against Eimeria acervulina in broilers fed a Lactobacillus spp-based probiotic. Poultry Science, v. 82, p. 62-66, 2003.

EDENS, F. W. An alternative for antibiotic use in poultry: probiotic. Revista Brasileira de Ciência Avícola, v. 5, n. 2, p. 75-97, 2003.

ERICKSON, K. L.; HUBBARD, N. E. Probiotic immunomodulation in health and diseases. Journal of Nutrition, v. 130, n. 2, p. 403-409, 2000.

FULLER, R. Probiotics in man and animals. Journal of Applied Bacteriology, v. 66, n. 5, p. 365-378, 1989.

FULLER, R. Probiotics. Journal of Applied Bacteriology, v. 60, n. 1, p. $1-6,1986$.

GU, X.; LI, D. Effect of dietary crude protein level on villous morphology, immune status and histochemistry parameters of digestive tract in weaning piglets. Animal Feed Science and Technology, v. 114, p. 113-126, 2004.

HAVENAAR, R.; SPANHAAK, S. Probiotics from an immunological point of view. Current Opinion in Biotechnology, v. 5, n. 3, p. 320-325, 1994.

JAHANIAN, R. Immunological responses as affected by dietary protein and arginine concentrations in starting broiler chicks. Poultry Science, v. 88, p. 1818-1824, 2009.

KIDD, M. T. et al. Growth and immunity of broiler chicks 
as affected by dietary arginine. Poultry Science, v. 80, p.1535-1542, 2001.

LILLEHOJ, H. Intestinal intraepithelial and splenic natural killer cell responses to Eimerian infections in inbtred chickens. Infection and Immunity, v. 57, p. 1879-1884, 1989.

LODDI, M. M. Probióticos, prebióticos e acidificantes orgânicos em dietas para frangos de corte. $2003.52 \mathrm{f}$. Tese (Doutorado em Zootecnia) - Faculdade de Ciências Agrárias e Veterinárias, Universidade Estadual Paulista Júlio de Mesquita Filho, Jaboticabal, 2003.

MENTEN, J. F. M. Probióticos, prebióticos e aditivos fitogênicos na nutrição de aves. In: SIMPÓSIO SOBRE INGREDIENTES NA ALIMENTAÇÃO ANIMAL, 2002, Campinas. Anais... Campinas: Colégio Brasileiro de nutrição animal, 2002. p. 251-276.

NG, S. C. et al. Mechanisms of action of probiotics: recent advances. Inflammatory Bowel Diseases, v. 15, n. 2, p. 300-310, 2009.

OLIVEIRA, M. N. et al. Aspectos tecnológicos de alimentos funcionais contendo probióticos. Revista Brasileira Ciências Farmacêuticas, v. 38 n. 1 p. 1-2, 2002.

PANCHENIAK, E. F. R. Isolamento, seleção, caracterização bioquímica e molecular para produção e avaliação do potencial probiótico de Lactobacillus 75 reuteri LPB P01-001 em suínos. 2005. 154 f. Tese (Doutorado em Tecnologia de Alimentos) - Universidade Federal do Paraná, Curitiba, 2005.

ROSELLI, M. et al. Prevention of TNBS-induced colitis by different Lactobacillus and Bifidobacterium strains is associated with an expansion of gamma delta $\mathrm{T}$ and regulatory $\mathrm{T}$ cells of intestinal intraepithelial lymphocytes. Inflammatory Bowel Diseases, v. 15, n. 10, p. 1526-1536, 2009.

ROSTAGNO, H. S. et al. Tabelas brasileiras para aves e suínos: composição de alimentos e exigências nutricionais de aves e suínos. Viçosa: UFV, 2005.

SCHAREK, L. et al. Influence of the probiotic Bacillus cereus var. toyoi on the intestinal immunity of piglets.

Veterinary Immunology and Imunopathology, v. 120, p. 136-147, 2007.

SCHNEITY, C.; NUOTIO, L. Efficacy of different microbial preparations for controlling Salmonella colonization in chicks and turkey poults by competitive exclusion. British Poultry Science, v. 33, n.1, p. 207-211, 1992.

SHARMA, J. M. Avian immunology. In: PASTORET, P. $P$. et al. Handbook of vertebrate immunology. Academic Press, 1998. p. 73-136.
ZHANG, L. B.; GUO, Y. M. Effects of liquid dl-2-hydroxy4-methylthio butanoic acid on growth performance and immune responses in broiler chickens. Poultry Science, v. 87, p.1370-1376, 2008.

Recebido em: 31.03.2015 Aceito em: 01.05.2015 